\title{
Petitioning, addressing and the historical imagination: the case of Great
}

\section{Yarmouth, England 1658-1784}

Ted Vallance

Department of Humanities, University of Roehampton, England

\section{SUMMARY}

This article examines the role of loyal addresses, petition-like texts that emerged during the Cromwellian Protectorate in England, as repositories of public memory. It contends that loyal addresses were a particularly mnemonic form of political communication: not only did addresses themselves incorporate historical narratives but their reproduction in contemporary newsbooks facilitated their later collection in compendia and histories of addressing. These volumes in turn gave an overall 'sense' or character to public opinion nationally and allowed its shifts to be charted over time. The article uses the case study of an address to Richard Cromwell issued in 1658 from the corporation of Great Yarmouth to demonstrate how this text was redeployed to wage a political

\footnotetext{
${ }^{1}$ I am grateful to Karin Bowie, Ed Legon, Thomas Munck, Andy Wood, and the Glasgow 'Political Petitioning' workshop participants for their comments on this paper. This article makes use of material from my forthcoming monograph Loyalty, Memory and Public Opinion in England, 16581727 (Manchester, 2019). I am grateful to Manchester University Press for permission to reproduce it here.
} 
campaign against leading magistrates in the town in the 1670s. The address gained renewed political significance in the late eighteenth century, as the interplay of local political and historical interests made its depiction of the influence of religious factions in the borough once again relevant. This local memory in turn fed upon a wider national use of the Cromwellian addresses as an example of political faithlessness and duplicity. Combined, these local and national discussions demonstrated the importance of addresses in defining public opinion and political identity over time.

This article explores the relationship between 'subscriptional texts' (in this case the petition-like form of the loyal address), public memory and the writing of history in early modern England. ${ }^{2}$ Addresses were texts which declared the loyalty of a community to authority. While they shared many similarities with petitions, there were certain features of this new type of subscriptional text which made it a particularly mnemonic form. First, addressing campaigns were national in scope. Second, allied to this, their content blended local concerns with national issues and/or events. Third, addressing activity was very public and predominately undertaken by official corporate bodies. Addressing activity therefore displayed the reflectiveness that Jürgen Habermas and Michael Warner have identified as being critical to the early modern public sphere. For

2 The term was coined by Mark Knights; see Knights, Representation and Misrepresentation in Later Stuart Britain: Partisanship and Political Culture (Oxford, 2005), p. 117. 
Habermas, the public that read and debated coffeehouse periodicals such as the Spectator 'read and debated about itself' ${ }^{3}$ For Warner, the emergence of 'temporally structured' publications was critical to the development of a public sphere, encouraging an awareness of the flow of debate and creating the sense of discussion 'currently unfolding in a sphere of activity'. ${ }^{4}$ The association of addresses with major events ensured that a sense of timeliness was built into this form of political communication. Yet, these were more than ephemeral publications: addressing activity quickly developed a consciousness of its own past through printed collections and histories of addressing which collated and commented upon these texts.

The article focuses on an address from the corporation of Great Yarmouth in East Anglia to Richard Cromwell, the new Lord Protector, in 1658. The address was one of many issued from counties, corporations and British colonies from late 1658 to early 1659 pledging loyalty to Richard. Through examining the political and historical use made of the Yarmouth address, this paper will explore the relationship between subscriptional activity and the writing of history. As will be shown, in the immediate post-Restoration period, the Yarmouth address was used to wage a political battle against major figures in the town corporation. The campaign initiated by the government informer, Richard Bower, against leading nonconformists was influenced by common

\footnotetext{
3 J. Habermas, The Structural Transformation of the Public Sphere, trans. T. Burger (Cambridge, 1992), p. 43.

4 M. Warner, Publics and Counterpublics (New York, 2002), pp. 95-6.
} 
contemporary political tropes linking dissent with sedition and the memory of civil war puritanism. Bower's attack on these members of the corporation was conducted through letters and grounded on the evidence of a surviving manuscript copy of the address. By the late eighteenth century, however, historical and political references to Yarmouth's address to Richard Cromwell had become embedded in print. While triggered by new factional struggles within the corporation, in turn fed by national debates over Britain's imperial crisis, these eighteenth-century representations of the address nonetheless continued to draw on the allusions made by Bower in the 1670s between dissent and political disloyalty. The case study of the Yarmouth address demonstrates that the much discussed value of subscriptional texts, especially petitions, in preserving the early modern 'social imaginary' ('the ways people imagine their social existence', as the philosopher Charles Taylor has described it), was grounded on their ability to act as repositories of public memory. ${ }^{5}$

\section{The loyal address}

5 C. Taylor, Modern Social Imaginaries (London, 2004), p. 23. For the social history of petitioning see S. Hindle, On the Parish? The Micro-Politics of Poor Relief in Rural England c.1550-1750 (Oxford, 2004), pp. 156-63, 407-28; R.A. Houston, Peasant Petitions: Social Relations and Economic Life on Landed Estates, 1600-1850 (Basingstoke, 2014); J. Healey, The First Century of Welfare: Poverty and Poor Relief in Lancashire, 1620-1730 (Woodbridge, 2014), chs 3-7; B. Waddell, God, Duty and Community in English Economic Life 1660-1720 (Woodbridge, 2012), esp. pp. 128-37; J. Peacey, Print and Public Politics in the English Revolution (Cambridge, 2013), esp. chs 8 and 10. 
Though clearly related to other forms of public praise, such as the panegyric, the loyal address was identified by contemporaries as a political innovation of the Cromwellian Protectorate: the pamphlet A Second Narrative of the Late Parliament (1659) claimed they were first concocted by Cromwell's secretary of state and spymaster, John Thurloe, and the regime's chief propagandist, Marchamont Nedham. ${ }^{6}$ The address would begin with a description of who the text was from (typically official bodies such as borough corporations or grand juries) and a statement of the occasion of the address (for example the accession of a new monarch), and end with a pledge of loyalty to the individual being addressed, whether the Lord Protector or, later, the monarch. The texts of addresses also usually involved some form of historical narration, by reflecting on past events and, through the pledge of loyalty, also seeking to determine future political conduct. This involved communities in acts of national storytelling which could become politically charged. To take the example of Yarmouth's address to James II on his accession in 1685, the corporation not only expressed sorrow at the death of Charles II but also gave thanks to God for thwarting the schemes of 'the faction [,] utter enemyes to the Monarchy and

6 A Second Narrative of the Late Parliament (so called) (1659), p. 37; M. Knights, 'The loyal address: prose panegyric 1658-1715', in A. McRae and P. Kewes (eds), Literature of the Stuart Successions (Oxford, 2017), ch. 16. 
Church of England' during the late king's reign. ${ }^{7}$ Yarmouth's 1685 address to James II also reflected, therefore, on the politics of the 'Exclusion Crisis' and the defeat of those politicians who had sought to bar James from inheriting his brother's title.

Texts of this kind would be agreed at corporation meetings or special sessions of the peace but to make these pledges of loyalty as authoritative as possible, addresses would be sealed and subscribed. Sometimes subscription was limited, for example to the members of the borough corporation, but there were also cases of mass addressing, such as the more than six thousand who were reported to have subscribed the Lincolnshire address to Richard Cromwell in $1659 .{ }^{8}$ The text would then be presented at court by leading members of the community, introduced by a courtier. A key incentive for communities in addressing either the Protector or the crown was the direct political access this activity secured. The value for authority was in the public display of loyalty delivered through the text. Reproduced in print via government-controlled newsbooks such as Mercurius Politicus and, post-Restoration, the London

\footnotetext{
7 Norfolk Record Office (hereafter NRO), Y/C 19/9, fo. 82v, Yarmouth Corporation Assembly Book, 16801701, 18 February 1685.

8 Mercurius Politicus, 17-24 March 1659, no. 559.
} 
Gazette, these addresses provided evidence of public support for authority and its policies. $^{9}$

Loyal addresses were clearly closely related to other, more established subscriptional forms, notably petitions. Indeed, when the term loyal or humble address first appeared in print in England in the 1640s and early 1650s, it was used simply as a synonym for petition. In the case of early modern Scotland, 'address' continued to refer to texts indistinguishable from petitions. ${ }^{10}$ Both petitions and addresses were supposed to be couched in deferential terms. Addresses were texts that congratulated, thanked and praised authority, but which were not supposed to make requests or place demands upon it (though in fact many addresses did). Consequently, addresses were attacked for offering little more than state-sponsored sycophancy: in the words of an antagonistic 1659 compendium of addresses to Richard Cromwell, these were 'lying, flattering addresses'. ${ }^{11}$ J.T. Rutt, the Victorian editor of Thomas Burton's parliamentary diary, similarly described them as 'vehicles of servile

9 On addressing, petitioning and political access see D. Hirst, 'Making contact: petitions and the English Republic', Journal of British Studies 45, (2006), pp. 26-50; and Vallance, Loyalty, Memory and Public Opinion in England, ch. 6.

10 See e.g. J. Lilburne, The banished mans suit for protection to his excellency the Lord Generall Cromwell. Being the humble address of Lieutenant Colonel John Lilburn (London, 1653); K. Bowie, Scottish Public Opinion and the Anglo-Scottish Union, 1699-1707 (Woodbridge, 2007), pp. 115-30.

11 [V. Powell], A true catalogue, or an account of the several places and most eminent persons ... where, and by whom, Richard Cromwell was proclaimed Lord Protector ([London, 1659]), p. 3. 
adulation'. ${ }^{12}$ However, recent work by Karin Bowie, Tim Harris, Mark Knights and Scott Sowerby has prompted a reassessment of these texts. Collectively, the work of these historians has demonstrated that addresses did not simply offer manufactured praise of authority: in Bowie's words, in order to be effective, they had to 'resonate with local grievances, attitudes and loyalties' ${ }^{13}$ In this way, Tim Harris has persuasively argued that the ebb and flow in the numbers of loyal addresses issued across the 1680s matched real shifts in public opinion. ${ }^{14}$ Both Bowie and Sowerby have shown the potential of addresses for building political coalitions in opposition to the Union in Scotland and in support of toleration in England. ${ }^{15}$ Mark Knights' work has demonstrated that, like petitions, loyal addresses could be used as vehicles for political controversy when issued in response to adversarial petitions and that the national scope of

12 J.T. Rutt, 'Introduction', in Diary of Thomas Burton Esq., 4 vols (London, 1828), vol. III, pp. iii-viii.

13 Bowie, Scottish Public Opinion, p. 6.

14 T. Harris, Restoration: Charles II and his Kingdoms (London, 2006), pp. 269, 315.

15 Bowie, Scottish Public Opinion, pp. 45-6 and ch. 6; S. Sowerby, Making Toleration: The Repealers and the Glorious Revolution (Cambridge, MA, 2013); Sowerby, 'Forgetting the repealers: religious toleration and historical amnesia in later Stuart England', Past and Present 215, (2011), pp. 85-123; see also B. Worden, 'The campaign for a free parliament, 1659-60', Parliamentary History 36, (2017), pp. 159-84; Worden, 'The demand for a free parliament, 1659-1660', in G. Southcombe and G. Tapsell (eds), Revolutionary England c.1630-c.1660: Essays for Clive Holmes (London, 2017), pp. 176-200. 
addressing campaigns meant that they contributed to a developing sense of national as well as partisan identity. ${ }^{16}$

This article focuses on an as yet under-explored aspect of addressing activity: its capacity to generate a public memory of fluctuations in political loyalty at both a local and a national level. The reproduction of addresses in print was critical here. The issuing of mass-subscribed printed petitions was identified post-Restoration as a 'great meanes of the late unhappy Wars Confusions and Calamities in this nation'. ${ }^{17}$ Some modern scholars, notably David Zaret, have also viewed the printing of petitions as having a revolutionary impact. ${ }^{18}$ However, as the research of Jason Peacey has shown, the printing of petitions was not always intended as a means of communicating with or representing a nebulous 'public': printed petitions could often be part of more discreet, varied and targeted communicative practices. ${ }^{19}$ In contrast, the publicizing of addressing activity via print was integral to it as a subscriptional

16 Knights, Representation and Misrepresentation, esp. ch. 3; see also Knights, 'Participation and representation before democracy: petitions and addresses in pre-modern Britain', in I. Shapiro, S.C. Stokes, E.J. Wood and A.S. Kirshner (eds), Political Representation (Cambridge, 2009), pp. 35-57.

17 'Charles II, 1661: An Act against Tumults and Disorders upon p[re]tence of p[re]paring or p[re]senting publick Petic[i]ons or other Addresses to His Majesty or the Parliament', in Statutes of the Realm: Volume 5, 1628-80, ed. J. Raithby (s.1., 1819), p. 308. British History Online http://www.british-history.ac.uk/statutesrealm/vol5/p308 [accessed 28 August 2017].

18 D. Zaret, Origins of Democratic Culture: Printing, Petitions and the Public Sphere in Early-Modern England (Princeton, 2000).

19 Peacey, Print and Public Politics, pp. 280-5. 
practice. The reproduction of loyal addresses in contemporary newsbooks such as Mercurius Politicus and Nouvelles Ordinaires de Londres helped to legitimize the Cromwellian Protectorate. For the communities addressing authority, whether the Lord Protector or subsequently the Stuart monarchy, the successful public display of loyalty was essential to securing political access and favour. ${ }^{20}$ As a result, addressing was an inherently 'public' activity. This in turn heightened its purchase upon the public memory.

As already noted, Michael Warner has argued that 'temporally structured' media are critical to the development of the public sphere. The sense of time fashioned by seventeenth-century newsbooks has been disputed by historians. Some recent work on early modern news media has emphasized its 'contemporaneity', its encouragement of an emerging sense of the 'now'. Daniel Woolf has argued that early modern news media created a 'detemporalised zone' which encouraged critical debate of contemporary politics in ways analogous to a Habermasian public sphere. ${ }^{21}$ As has been suggested in a recent article by Tony Claydon, however, the 'permanent separation of news from history' identified by Woolf was perhaps less final than he contends. The vagaries of early modern transport networks, the difference between the

20 For a frank statement of this, see the draft address from the Lancashire grand jury to Charles II at his restoration contained in Historical Manuscripts Commission, Fourteenth Report, Appendix, Part IV, The Manuscripts of Lord Kenyon (London, 1894) p. 68.

21 D. Woolf, 'News, history, and the construction of the present in early modern England', in S.A. Baron and B. Dooley (eds), The Politics of Information in Early Modern Europe (London, 2001), pp. 80-108, at p. 108. 
Gregorian and Julian calendars and the limitations of the format of the early modern newsbook all contributed, Claydon argues, to news often appearing more as a historical chronicle rather than existing 'in an evolving present' ${ }^{22}$ This was not least, as Noah Millstone has demonstrated, because early modern printed newsbooks, in both England and continental Europe, were frequently designed to be collected and collated, with these collections in turn being employed by contemporaries as vital reference works for the writing of history. ${ }^{23}$

This aspect of early modern news culture is very clearly demonstrated in the case of addresses. Compendia of addresses emerged very shortly after the practice itself became established, with A true catalogue appearing in late $1659,{ }^{24}$ only months after the campaign of addresses to Richard Cromwell had ended, its content clearly indebted to the pages of contemporary newsbooks. These compendia were often highly critical; in the case of A true catalogue, deploying these texts to attack the back-sliding and hypocrisy of many former

22 Woolf, 'Construction of the present', p. 98; T. Claydon, 'Daily news and the construction of time in late Stuart England, 1695-1714', Journal of British Studies 52, (2013), pp. 55-78, at p. 74.

23 N. Millstone, 'Designed for collection: early modern news and the production of history', Media History 23, (2017), pp. 177-98. For newspaper collecting see also U. Heyd, Reading Newspapers: Press and Public in Eighteenth-century Britain and America (Oxford, 2012), ch. 6, and Claydon, 'Daily news', p. 75.

${ }^{24}$ See note 10 above. 
adherents of the 'Good Old Cause'. ${ }^{25}$ This compendium suggested that many of the addresses sent to Richard Cromwell, including that from Great Yarmouth, were in fact much more equivocal pledges of loyalty than they at first appeared. Compendia therefore did not simply collect texts but also 'spun' them, attempting to give an overall shape or character to public opinion at a particular historical moment. The editorializing of addresses was facilitated by their mimetic quality: communities commonly played a game of 'follow the leader', adapting texts previously produced by other counties or corporations, a practice in turn supported by the publicizing of loyal addresses in news media. ${ }^{26}$ The biblical allusion to Oliver Cromwell as Moses and his son as Joshua, for example, was repeated so frequently in the addresses to Richard Cromwell that A true catalogue chose to mark these instances up to indicate what the author saw as the suspect uniformity of the Cromwellian texts. ${ }^{27}$

These collections were themselves reprinted and redeployed for political effect. In the wake of the Jacobite Atterbury plot of 1722, for example, a

25 For collections of addresses see W. Caton, Truths caracter (London, 1660); T. Fuller, A happy handfull (London, 1660); Vox patriae (London, 1681); Vox Angliae (London, 1682); A collection of the several addresses in the late King James's time ([London, 1710]); A collection of the addresses which have been presented to the Queen since the impeachment of the reverend Dr. Henry Sacheverell (Parts 1 and 2, London, 1710-11); A collection of addresses \&c. (London, 1710); The addresses to King George II on his accession to the throne (London, 1727); The voice of the people: a collection of addresses to his majesty (London, 1756).

26 G. Davies, The Restoration of Charles II, 1658-1660 (San Marino, 1955), p. 11.

27 A true catalogue, pp. 37-8. 
collection appeared reprinting addresses from Scottish and English Presbyterians congratulating James II on the birth of the Prince of Wales in $1688 .^{28}$ The conclusion to be drawn from these addresses was made plain by the anonymous compiler: 'I'm sure, whoever reads them, cannot think but the Addressers were the greatest Jacobites in the World.' Yet it was these same groups, the compiler noted, who were the first to forsake James at the revolution, even though their earlier promises of loyalty contained no reservations 'unless Jesuitical or mental'. ${ }^{29}$

By the early eighteenth century, the mnemonic aspects of addressing activity were further revealed in the creation of histories of addressing by writers such as Daniel Defoe, Benjamin Hoadly and John Oldmixon. ${ }^{30}$ These predominately Whig histories were intended to counter collections of Tory addresses which sought to show that the weight of public opinion was on their

28 A collection of addresses presented by the English and Scottish Presbyterians to King James VII ([Edinburgh, 1722]).

29 A collection of addresses presented by the English and Scottish Presbyterians to King James VII ([Edinburgh, 1722]).p. 8.

30 [D. Defoe], A new test of the sence of the nation: being a modest comparison between the addresses to the late King James, and those to her present majesty (London, 1710); [J. Oldmixon], The history of addresses. With remarks serious and comical. In which a particular regard is had to all such as been presented since the impeachment of Dr. Sacheverell (London, 1711); [B. Hoadly], The voice of the addressers, or a short comment on the chief things contain'd, or condemn'd in our late modest addresses (London, 1710). 
side. ${ }^{31}$ They were thus not only trying to capture and influence a national picture of public opinion but also seeking to map how opinion had shifted over time.

The mnemonic qualities of addressing activity, however, were not solely a product of the preservation of these texts in contemporary printed news media. The case study of the Great Yarmouth address to Richard Cromwell produced in 1658 reveals that manuscript records of subscription were also critical. Equally, the nature of addresses as typically corporate and official statements of loyalty also facilitated their remembrance. This meant that these texts could not only remain politically 'live' long after their original creation but also provide a means of integrating local history with a national narrative.

\section{The Great Yarmouth Address}

Richard Bower, a Great Yarmouth coffeehouse keeper, was a regular correspondent of Charles II's secretary of state and chief intelligence gatherer, Sir Joseph Williamson. Between 1662 and 1679 he provided Williamson with information concerning two essential topics: shipping and - the issue which exercised him most - the activities of the town's nonconformists, identified by him as Presbyterians and Independents. On 12 July 1676, Bower wrote to Williamson enclosing a manuscript copy of:

31 Notably those anthologized in the printer John Morphew's A collection of the addresses which have been presented to the Queen since the impeachment of the reverend Dr. Henry Sacheverell (Parts 1 and 2, London, 1710-11). 
our towne's Address to Rich., Protector, (wch came from one yt was formerly of theire Assembly), where you will finde severall of our new militia officers, as our Coll, Sr George England, our Maior, Bayliff Thaxter: \& Capt. Richard Huntington, besides severall of ye old Presbiterian gang, that are at present justices \& aldermen of our towne, whoo are marked wth P. there is alsoe ye chiefe of our Independts now in towne marked wth I... if you please to $\mathrm{p}$ [er]use ye Address from this towne to Richard, Protector: you will finde those cheifly concerned in yt Address, to have ye greatest share in the government of this towne from ye yeare '65 to this present day, from whence the Nonconformists here, tooke encouragement to contemne both ye laws \& ye King's Comands \& to grow So numerous as now they are. ${ }^{32}$

Bower's concern with the influence wielded by men such as England and Thaxter was long-standing - indeed, he had supplied his own narrative history of the town to Williamson, detailing what he saw as the takeover of the

32 The National Archives, Kew (hereafter TNA) SP 29/383, fos 140-142. The copy Bower sent Williamson can be found in TNA SP 18/184, fo. 145-145v, placed in the volume for December 1658, but with the names of subscribers clearly marked up as indicated above. I am grateful to Ed Legon for alerting me to Bower's correspondence and the address. See E.J. Legon, 'Remembering revolution: seditious memories in England and Wales, 1660-1685' (University College, London, PhD thesis, 2015), pp. 76-7, and for Bower and the address P. Gauci, Politics and Society in Great Yarmouth, 1660-1722 (Oxford, 1996), pp. 103-4, $136-43$. 
corporation by men who had been supporters of the 'late rebellion'. ${ }^{33}$ The connections between Yarmouth's current governors and the Parliamentarian cause were repeatedly emphasized in Bower's letters: he assiduously reported the reputed presence of the old Cromwellians Oliver St John and John Desborough in the area and gave detailed accounts of the activities of the veteran Independent minister William Bridges; he noted the refusal of men including Bridges' son-in-law to renounce the Parliamentarian Solemn League and Covenant; and he attributed the confidence of the town's nonconformists to the fact that the militia was now in the hands of men who 'joined with them in the government in the late unhappy times' ${ }^{34}$ These specific, local accusations were connected to Bower's broader view, also articulated to Williamson, that dissenters were primarily responsible for the civil war. ${ }^{35}$

It was remarkable, in the first place, that the address had come into Bower's possession at all. Yarmouth corporation had ordered on 3 January 1661 that 'the Addresse made to Richard Cromwell (the late pr[e]tended Protector[)] by this house be utterly disclaimed obliterated and made void'. ${ }^{36}$ The order could be seen as an essentially symbolic gesture, a sort of local 'Act of Oblivion', as the Yarmouth address had already been printed in both Mercurius

\footnotetext{
33 TNA SP 29/230, fo. 103-103v.

34 TNA SP 29/249, fo. 14 (William Bridges); TNA SP 29/262, fo. 19 (St John and Desborough); SP 29/265, fo. 84 (refusal to swear Covenant); SP 29/382, fo. 72 (militia).

35 TNA SP 29/363, fo. 108.

36 NRO, Yarmouth Corporation Assembly Book 1642-1662, Y/C 19/7, fo. 371.
} 
Politicus and Nouvelles Ordinaires, as well as being reproduced in A true catalogue. ${ }^{37}$ However, the iterations of the address which appeared in print did not include the names of subscribers. The 1661 order may then also have been motivated by a desire to conceal the past actions of those civic officers who survived the post-Restoration purges.

For Bower, the manuscript copy of the Cromwellian address represented an evidentiary 'smoking gun', providing documentary proof of the informer's long-standing claims about Yarmouth's magistrates and their political disloyalty. Bower's letter is indicative of the persistence of the memory of the addressing activity of the Cromwellian period and its importance to political debates in the latter years of Charles II's reign. ${ }^{38}$ Indeed, his letter suggests that references in print during the Exclusion Crisis to the Cromwellian addresses may have been grounded on local memory as well as surviving records in contemporary newsbooks. ${ }^{39}$ Bower's letter indicated that some members of the corporation had preserved a copy of the address, sensing that it might prove politically useful at a later date. If so, they were not alone: a pamphlet printed in

37 A true catalogue, pp. 29-30.

38 On this see M. Knights, Politics and Opinion in Crisis, 1678-1681 (Cambridge, 1994), pp. 321-2; Vallance, Loyalty, Memory and Public Opinion, ch. 3.

39 For print references see [Attrib. Earl of Shaftesbury], An impartial account of the nature and tendency of the late addresses in a letter to a gentleman in the country ([London], 1681), p. 4; The addresses importing an abhorrence of an association. Pretended to have been seized in the E. of Shaftsbury's closet, laid open and detected (London, 1682), p. 3; An historical account of the rise and progress of addressing (London, 1681), p. 2. 
1682, detailing disputes over the production of a loyal address to Charles II from the borough of Wells, Somerset, compared this text with that provided by the same borough to Richard Cromwell. Like Bower, the pamphleteer used the records of subscription to the Cromwellian address to smear town leaders, intimating that those who had signed it were the fathers of civic officers who had recently sought to obstruct the loyal text to the king. ${ }^{40}$ Bower similarly used the Yarmouth address to add weight to a royalist narrative of the town's recent political history in which influential Presbyterians and Independents used their position of authority to protect and encourage dissent in the town, fostering a faction which flouted the laws and treated the crown's authority with contempt. In this way, Bower's letter complemented already established links, noted above, between sedition and subscriptional activity, and between dissent and civil war puritanism.

In fact, Bower's letter almost certainly exaggerated the commitment of Yarmouth's officials to the Cromwellian regime. While the corporation received the proclamation announcing Richard's succession in early September and celebrated the event shortly afterwards, it would not be until November 1658 that the town would agree on the text of an address and only in early 1659 that

40 The proceedings of the grand jury at Taunton (1682); the address was first reproduced in Nouvelles Ordinaires, 4-11 November 1658, no. 442, but without any details regarding the subscribers, indicating that the author of the pamphlet was working from either the original address or, like Bower, a manuscript copy. 
the address appeared in print. ${ }^{41}$ It is notable, in contrast, that when Charles II was restored to the throne, the corporation was able to appoint the committee to produce an address and agree the text all in the same day. ${ }^{42}$ In common with many other addresses sent to Richard Cromwell, Yarmouth's 1658 text avoided direct acknowledgement of Richard's right to rule as conferred through the Humble Petition and Advice, instead preferring to emphasize the role of divine providence. The use of providence in these addresses, as I have suggested in greater detail elsewhere, far from simply being a means of flattering Richard as a new 'Joshua' (the most common biblical allusion in these texts), was actually a means of avoiding publicly endorsing either the Protectoral constitution or the new Protector's legal title. ${ }^{43}$ Bower then, like the compiler of A true catalogue, was 'spinning' the content of the Yarmouth address to emphasize the dubious political loyalties of some of the town's magistrates.

Even if Yarmouth's address had offered rather lukewarm support for Richard's protectorate, Bower's claim that current magistrates had been involved in making a public declaration of loyalty to the Lord Protector was

41 NRO, Y/C 19/7, fo. 312, Yarmouth Corporation Assembly Book, 1642-1662, 6 September 1658 (receipt of proclamation announcing Richard's succession); ibid., fo. 315v, 8 November 1658 (appointment of a committee to draw up the address); ibid., fo. 316, 18 November 1658 (address agreed and order given for it to be presented). Nouvelles Ordinaires, 7-16 September 1658, no. 434, reports celebrations of Richard's succession in Yarmouth; Mercurius Politicus, 30 December to 6 January, 1658/59, no. 548, reproduces Yarmouth address. See also Nouvelles Ordinaires, 24 February to 5 March 1659, no. 458.

42 NRO, Y/C 19/7, fos 356v-357, Yarmouth Corporation Assembly Book, 1642-1662, 8 August 1660.

43 Vallance, Loyalty, Memory and Public Opinion, ch. 2. 
clearly felt to be highly damaging. The letter was leaked to Edmund Thaxter, Richard Huntington and George England, possibly by Williamson via Robert Paston, Viscount Yarmouth, the Lord Lieutenant of Norfolk. ${ }^{44}$ As Viscount Yarmouth's legal counsel, William Thursby, noted, although Bower's letter was certainly 'very saucy \& censorious' (and thereby actionable under law), the first two charges within it (that some of the magistrates had collaborated with the Cromwellian regime and that they had since connived at nonconformist meetings) had enough substance to them to be politically harmful if aired publicly. Thursby therefore advised that the charges should be heard at the local assizes rather than before the privy council. ${ }^{45}$

This advice went against the wishes of the men Bower had targeted in his letter. Thaxter, Huntington and England urged both Williamson and Viscount Yarmouth (who had also been accused by Bower of having turned a blind eye to the presence of dissenters in the militia) to take action against Bower. ${ }^{46}$ In their correspondence with Viscount Yarmouth, the magistrates attempted to turn the tables on Bower by accusing him of having been listed in a "troop raised for plunder \& decimation under Col[one]l Brewster' that 'complyed most exactly with all the proceedings of the usurped powers \& authority in the late

44 TNA SP 29/392, fo. 3.

45 J. Agnew (ed.), The Whirlpool of Misadventures: Letters of Robert Paston, First Earl of Yarmouth, 16631679 (Norfolk Record Society, LXXVI, 2012), pp. 249-50; TNA SP 29/386, fo. 141.

46 TNA SP 29/384, fo. 169. 
troublesome \& rebellious times' ${ }^{47}$ Together, the magistrates and Viscount Yarmouth succeeded in having Bower's coffee business shut down and Bower himself bound over for good behaviour. This action had the double advantage of punishing Bower financially and helping to cut off his supply of news. ${ }^{48}$ (As Bower himself had admitted, he had used the coffee business for the 'better gaining of intelligence'. $)^{49}$

Nonetheless, Bower could not be induced to retract his claims fully. As Joanna Innes and Rachel Weil have observed, informing could give those of lower social status leverage over their superiors. ${ }^{50}$ In Bower's case, we are presented with a mere 'coffee howse man' questioning the political loyalties and conduct of wealthy merchants, gentlemen and (in the case of Paston) aristocrats. $^{51}$ As Edmund Thaxter complained to Williamson, it was unacceptable that the magistrates should be 'awed by so inconsiderable a

47 Agnew (ed.), Paston Letters, p. 241.

48 TNA SP 29/386, fos 67, 98; Agnew (ed.), Paston Letters, pp. 256-7, 264-5, 268; Gauci, Great Yarmouth, pp. 136-8.

49 TNA SP 29/386, fo. 67.

50 J. Innes, Inferior Politics: Social Problems and Social Policies in Eighteenth-century Britain (Oxford, 2009), ch. 7; R. Weil, A Plague of Informers: Conspiracy and Political Trust in William III's England (Yale, 2013), p. 24.

51 Agnew (ed.), Paston Letters, p. 176. Bower asserted that the coffee business in fact belonged to his wife (TNA SP 29/384, fo. 162; SP 29/385, fo. 207; SP 20/386, fo. 67) but this is contradicted by British Library Sloane MS 645, fo. 19 which includes three recipes from Bower for coffee, coffee powder and hot chocolate. 
fellow' ${ }^{52}$ In attempting to undermine the credibility of Bower's claims, Thaxter, England and Huntington even investigated the informer's pedigree, enquiring with the herald's office as to his genealogy and ascertaining that he was originally from Yorkshire, his father a writing master. ${ }^{53}$ The problem, however, was that though the efforts of Thaxter and his colleagues had 'humbled' Bower's 'purse' yet his 'spirit' was as 'high as ever' ${ }^{54}$ Bower's repeated threats to reiterate his claims in court and even to reproduce them in print seem to have been effective: Viscount Yarmouth was forced to intercede and have the trial at the assizes called off. In his letter to Williamson reporting this, Viscount Yarmouth claimed that he would be prepared to forgive Bower for his accusations, especially as he was such an 'inconsiderable fellow'. ${ }^{55}$ This façade of equanimity was not maintained in a letter written the same day to his wife, in which Viscount Yarmouth fumed that if Williamson did not do something to 'humble the insolence of that fellow I must afterwards downe right fall on him' ${ }^{56}$

Bower's correspondence with Williamson dropped off significantly after 1678 , indicating that pressure had been brought to bear on him to cease his

\footnotetext{
52 TNA SP 29/384, fo. 169.

53 Agnew (ed.), Paston Letters, pp. 264-5.

54 Agnew (ed.), Paston Letters, p. 265.

55 TNA SP 29/402, fo. 112. For Bower's threat to publish see SP 29/405, fo. 307; SP 29/408, fo. 37.

56 Agnew (ed.), Paston Letters, p. 326.
} 
activities as an informer. ${ }^{57}$ The attempt to silence Bower had only been partially successful, however, and his remarks about the magistrates had, by their own admission, become 'the common subject of discourse' in the town. ${ }^{58}$

\section{Addresses, politics and local history}

The lengthy and high-profile nature of this dispute, spanning two years and involving members of the privy council as well as the Yarmouth corporation, partly explains why it continued to be recalled in the eighteenth century. Yet, the memory of the Cromwellian address arguably was also sustained because of the enduring local political value of the text. A second manuscript copy of the 1658 Yarmouth address survives transcribed into the back of the corporation's assembly book, inserted at a later date (probably in the eighteenth century) and taken from another copy held by Joseph Cotman. ${ }^{59}$ The Cotmans were an important political family in eighteenth-century Yarmouth. Two Joseph Cotmans were elected mayor in the 1700s, the first in 1704 , the second, his grandson, in 1745, 1757 and again in $1759 .{ }^{60}$ There were plausible reasons for

\footnotetext{
57 There is a gap of four years between his last letter to Williamson (3 February 1679, TNA SP 29/411, fo. 144) and his final letter in State Papers (to Leoline Jenkins) in April 1683 (TNA SP 29/423, fo. 184).

58 Agnew (ed.), Paston Letters, p. 268.

59 NRO Y/C 19/7, fos 406-407, Yarmouth Corporation Assembly Book, 1642-1662.

60 Francis Blomefield, 'East Flegg Hundred: Great Yarmouth, bailiffs and mayors', in An Essay Towards a Topographical History of the County of Norfolk: Volume 11 (London, 1810), pp. 322-45. British History
} 
both Cotman senior and junior to have kept a copy of the address. The first Joseph Cotman was preceded as mayor by Benjamin England who would later become MP for the town, as would his brother George England and nephew, also George England. ${ }^{61}$ If the address was preserved by this Joseph Cotman, then the intention was probably to use it in the same fashion as had Richard Bower: to embarrass political rivals by pointing to their family's past collusion with the Cromwellian regime.

There is also evidence, however, pointing to the copy being kept by the second Joseph Cotman. This Joseph Cotman was involved in a disputed mayoral election in 1758-59 which led to a court case at the Norfolk assize, eventually resolved in Cotman's favour. ${ }^{62}$ As part of the crown's case against Cotman, however, he was accused of taking 'Bookes, Records, and Papers belonging to the Corporation of Great Yarmouth'. ${ }^{63}$ The younger Joseph Cotman had enjoyed access to the corporation's records as a long-standing

Online http://www.british-history.ac.uk/topographical-hist-norfolk/vol11/pp322-345 [accessed 28 August 2017].

61 'England, Benjamin', in D. Hayton, E. Cruickshanks and S. Handley (eds), The History of Parliament: The House of Commons 1690-1715 (Woodbridge, 2002), http://www.historyofparliamentonline.org/volume/1690-1715/member/england-benjamin-1647-1711 [accessed 20 November 2017].

${ }^{62}$ C.J. Palmer, The History of Great Yarmouth designed as a continuation of Manship's history (Great Yarmouth and London, 1856), p. 316.

63 NRO Y/C 36/19/20, letter from John Ramey, attorney for the prosecution in Rex vs. Cotman, 10 March 1760. 
member (and sometime treasurer) of the committee for the 'Hutch' (as the corporation archive was known). ${ }^{64}$ The case itself hinged on the established procedures for meetings of the Great Council of the borough, as well as for the election of the mayor, making access to the town's records critical to the prosecution brief. ${ }^{65}$ The opposing candidate in this case, William Browne, and the prosecutor, John Ramey, were both former opponents of the TownshendWalpole interest which dominated the town's politics. Both had been bought off. ${ }^{66}$ Cotman junior perhaps alighted on the Cromwellian address as evidence of the historic pusillanimity of the corporation in the face of powerful vested interests.

The appearance of the address in histories of Great Yarmouth published in the later eighteenth century may also indicate that it was Cotman junior who secured the copy. Mention of the address was notably absent from Francis Blomefield's Topographical History of Norfolk, first published in 1739 and, after Blomefield's death in 1752, completed by the antiquary Charles Parkin. The address did appear, however, in Henry Swinden's 1772 history of the

64 NRO Y/C 19/3, Yarmouth Corporation Assembly Book, 1750-1771, 12 March 1751 (appointed to committee); 15 November 1751 (made foreman); 29 November 1751 (listed as treasurer).

65 NRO YC 36/19/22 (brief on motion against Cotman).

66 Palmer, History of Great Yarmouth, p. 220. For Ramey see 'Great Yarmouth' in The History of Parliament: The House of Commons 1754-1790, eds L. Namier and J. Brooke (London, 1964), http://www.historyofparliamentonline.org/volume/1754-1790/constituencies/great-yarmouth [accessed 8 November 2017]. 
borough. ${ }^{67}$ Swinden, whose history was commissioned by the corporation, reproduced the address as a 'specimen of the style and oratory of the ruling Party of those times' ${ }^{68}$ These reflections on the Yarmouth address in Swinden's history may also have been informed by the broader references to the Cromwellian addresses in eighteenth-century historical and antiquarian works. ${ }^{69}$ Some of these historical works included barely disguised commentary on the continuing use of loyal addresses in the eighteenth century. Referring to the example of the addresses sent to Richard Cromwell, Sir John Dalrymple remarked in a volume published in 1771 that 'addresses are, in Britain, generally the effects of party and example, but seldom the voice of the nation, or of reason' ${ }^{70}$

67 H. Swinden, The History and Antiquities of the Ancient Burgh of Great Yarmouth (Norwich, 1772), pp. 5789; Palmer, History of Great Yarmouth, p. 245.

68 Swinden, History and Antiquities of Great Yarmouth, p. 578; Norfolk Record Office Information Leaflet 24, Historians of Great Yarmouth, http://www.archives.norfolk.gov.uk/view/NCC098510 [accessed 18 August 2017]; Fell-Smith, Charlotte. 2004 "Swinden, Henry (1716-1772), antiquary." Oxford Dictionary of $\begin{array}{lllll}\text { National } & \text { Biography. } & 12 & \text { Sep. } & 2018 .\end{array}$ http://www.oxforddnb.com/view/10.1093/ref:odnb/9780198614128.001.0001/odnb-9780198614128-e26838, (hereafter $O D N B$ ).

69 [John Oldmixon], The history of addresses. By one very near a kin to the author of the Tale of a Tub (1709), p. 8; [Defoe], A new test of the sence of the nation, p. 16; [B. Hoadly], The high church mask pull'd off or, the modern addresses anatomized (1710), p. 7; Reliquiae Hearnianae: P. Bliss (ed.), The Remains of Thomas Hearne M.A., 3 vols (London, 1869), vol. 1, pp. 257-8; M. Noble, Memoirs of the ProtectoralHouse of Cromwell, 3rd edn, 2 vols (London, 1787), vol. I, pp. 181-2.

70 Sir J. Dalrymple, Memoirs of Great Britain and Ireland (Dublin, 1771), p. 3 and n. 
The continued political use of addresses in the later eighteenth century, therefore, also sustained the memory of addressing activity. As the research of James Bradley has shown, from 1768 to 1784 , there was a concerted attempt to wrest power away from the Townshend-Walpole axis in Great Yarmouth. The opposition was led by the town's lay dissenters, especially the wealthy Presbyterian merchant family, the Hurrys. ${ }^{71}$ While the Cromwellian address could be employed, once again, to connect nonconformity with civil war puritanism, the address could also be used to criticize those who slavishly pledged their loyalty to the political status quo. That allusion was made clear in another eighteenth-century history of the borough, which described the address as a 'most curious specimen of abject servility, and fulsome adulation, (not to say blasphemy), we cannot refuse it a place, disgraceful as it is to the annals of the town, and the principles of the progenitors of the good people of Yarmouth' ${ }^{72}$ The revival of historical interest in the Cromwellian addresses, in turn, may have helped inform contemporary political argument: in 1784, a number of press reports connected a recent addressing campaign, initiated by and in defence of the East India Company, with the addresses sent to Richard

71 J.E. Bradley, Popular Politics and the American Revolution in England: Petitions, the Crown and Public Opinion (Macon, GA, 1986), pp. 158-60.

72 'C. Parkin', The History of Great Yarmouth, Collected from Antient Records and other Authentic Materials (Lynn, 1776), p. 317. For the authorship of this history see D. Stoker, 'Parkin, Charles', ODNB and Stoker, 'Mr Parkin's Magpie, the Other Mr Whittingham and the Fate of Great Yarmouth', The Library, series 6, 12, (1990), pp. 121-31. 
Cromwell. ${ }^{73}$ In Great Yarmouth, these past and present national addressing campaigns were then reconnected with local memory: one anonymous correspondent to the Norfolk Chronicle attacked a loyal address from Yarmouth in 1784 as a product of the old 'Oliverian leaven', there being 'an Address on record, signed by the ancestors of some of the present Addressers, to the Protector Richard Cromwell, on the decease of Oliver' ${ }^{74}$ Set against the broader context of imperial crisis, petitioning and addressing were once again highly politicized activities at both a local and national level.

By the nineteenth century, the town's submission to Richard Cromwell had become embedded in local history. The address was mentioned in Chamber's history of Norfolk, published in two volumes in 1829 . Here the text, described as 'fulsome, fanatical cant', was seen as indicative of the borough's political hypocrisy: by obliterating the address of 1658 and sending a loyal text to Charles II in 1660, 'the addressers of Richard Cromwell seem to have purchased the favours of Charles II'. ${ }^{75}$ It was also discussed in detail in Charles Palmer's The History of Great Yarmouth designed as a continuation of Manship's history, published in 1856. Indeed, Palmer told the history of

73 Gazetteer and New Daily Advertiser, 26 January 1784, no. 17199; Parker's General Advertiser and Morning Intelligencer, 12 June 1784, no. 2364; for the campaign, C. Philips, 'The East India Company "Interest" and the English Government, 1783-4', Transactions of the Royal Historical Society 20, (1937), pp. 83-101, at p. 88.

74 Norfolk Chronicle, 7 February 1784, no. 766; for a reply see Norfolk Chronicle, 21 February 1784, no. 768.

75 [J. Chambers], A General History of Norfolk, 2 vols (Norwich, 1829), vol. I, pp. 288-9. 
Yarmouth from the late seventeenth century to the early nineteenth century largely through the town's addressing activity. ${ }^{76}$ While this was clearly a product of Palmer's greater engagement with archival materials (his history closely followed the detail of the corporation's assembly books), it was also arguably recognition of the way in which addressing activity connected the local with the national. The corporation's addresses provided Palmer with a means of showing Yarmouth's role in major events, whether the North Briton case or the American and French revolutions.

\section{Conclusion}

Palmer's Victorian history of the town ensured that Yarmouth's submission to the second Lord Protector, Richard Cromwell, is remembered even in the twenty-first century: Frank Meeres' 2007 history of the borough offered only a brief political history of the town yet still found space to mention the Cromwellian address. ${ }^{77}$ Palmer's work had been intended as a modern continuation of the manuscript civic histories of the town written by Henry Manship and Thomas Damet. ${ }^{78}$ As Jan Broadway has observed, the purpose of

\footnotetext{
76 Palmer, History of Great Yarmouth, pp. 247-70.

77 F. Meeres, A History of Great Yarmouth (Chichester, 2007), p. 26.

78 On which see A. Wood, 'Tales from the "Yarmouth Hutch": civic identities and hidden histories in an urban archive', Past and Present 230 (Suppl. 11), (2016), pp. 213-30; R. Tittler, 'Henry Manship: Constructing the civic memory in Great Yarmouth', in Townspeople and Nation: English Urban Experiences, 1540-1640 (Stanford, 2001), ch. 5.
} 
much early modern local history was didactic: to provide instruction in 'civic virtue and personal conduct'. ${ }^{79}$ The preservation of Yarmouth's Cromwellian address might be seen to fit with a Tacitean conception of the role of history, not only in celebrating virtuous actions but also in threatening 'with disgrace in the eyes of posterity' those who had committed wrongs in word or deed ${ }^{80}$ For Richard Bower, Yarmouth's address supported his narrative of the town's postRestoration politics which saw the corporation captured by nonconformists of dubious loyalty from the mid-1660s onwards. This local narrative in turn mapped onto parallels that were repeatedly being drawn in national political discourse, including in the texts of printed loyal addresses, between Restoration dissent and civil war puritanism. ${ }^{81}$ The inclusion of addressing activity in many other seventeenth-century memoirs, diaries, and private and public histories all point to the capacity of these texts to connect individual and local experience with broader shifts in public opinion. ${ }^{82}$ In the case of Yarmouth, the

79 J. Broadway, 'No historie so meete': Gentry Culture and the Development of Local History in Early Modern England (Manchester, 2006), p. 181.

80 Tacitus quoted in Broadway, 'No historie so meete': Gentry Culture and the Development of Local History in Early Modern England, pp. 180-1.

81 For examples see Impartial Protestant Mercury, 2-5 August 1681, no. 30 (Northumberland Lieutenancy); The Loyal Protestant and True Domestick Intelligence, 6 August 1681, no. 44 (Leeds); The Loyal Protestant and True Domestick Intelligence, 23 March 1682, no. 132 (address of Southampton Grand Jury); The Humble Address of the Grand Jury of and for the Town and Burrough of Southwark ([London], 1683).

82 For examples see A. Browning, (ed.), revised by M.K. Geiter and W.A. Speck, Memoirs of Sir John Reresby: The Complete Text and a Selection from his Letters (London, 1991); R. Spalding (ed.), The Diary 
preservation of records of subscription was especially important. This was not just because such records could be used to hold individuals (and their descendants) to account for their past political conduct but also because, as noted by Mark Knights, addresses could be used to fashion group identities. There were parallels here between the gloss placed by Bower on the Yarmouth address and the broader 'spin' placed on the Cromwellian addresses in compendia such as A true catalogue. In this respect, the Cromwellian addressing campaigns remained a potent exemplar of political duplicity well into the eighteenth century, especially in a town such as Yarmouth where nonconformists (and nonconformist dynasties) remained politically influential. Mark Knights has noted that addressing activity contributed to a general anxiety during the 'Rage of Party' about the credibility of political argument and the stability of political discourse ${ }^{83}$ The mnemonic quality of addressing, however, could also facilitate navigating the complex and shifting late seventeenth and eighteenth-century political landscape, fixing political identities and mapping individual, local and national loyalties over time.

\section{Notes on Contributor}

of Bulstrode Whitelock 1605-1675 (Oxford, 1990); R.A. Anselment (ed.), The Remembrances of Elizabeth Freke, 1671-1714 (Camden Society, 5th series, 18, Cambridge, 2001).

83 M. Knights, 'Introduction: The view from 1710', Parliamentary History 31, (2012), pp. 1-15, at pp. 13-15; Knights, Representation and Misrepresentation, ch. 3 esp. pp. 149-62. 
Edward (Ted) Vallance is Professor of Early Modern British Political Culture at the University of Roehampton, London, England. He is the author of $A$ Radical History of Britain (London, 2009), The Glorious Revolution (London, 2006) and Revolutionary England and the National Covenant (Woodbridge, 2005). With Harald Braun he has edited two volumes on conscience and casuistry in early modern Europe: Contexts of Conscience (Basingstoke, 2004) and The Renaissance Conscience (Oxford, 2011). His next book, Loyalty, Memory and Public Opinion in England, 1658-1727, will be published by Manchester University Press in 2019. 